\title{
Chryseobacterium culicis sp. nov., isolated from the midgut of the mosquito Culex quinquefasciatus
}

\author{
Correspondence \\ Peter Kämpfer \\ peter.kaempfer@umwelt. \\ uni-giessen.de \\ Vijay Veer \\ vijayveer50@yahoo.com
}

\author{
Peter Kämpfer, ${ }^{1}$ Kshitij Chandel, ${ }^{2}$ G. B. K. S. Prasad, $^{3}$ Y. S. Shouche ${ }^{4}$ \\ and Vijay Veer ${ }^{2}$ \\ ${ }^{1}$ Institut für Angewandte Mikrobiologie, Justus-Liebig-Universität Giessen, Heinrich-Buff-Ring \\ 36-32, D-35392 Giessen, Germany \\ ${ }^{2}$ Defense Research and Development Establishment, Jhansi Road, Gwalior 474 002, India \\ ${ }^{3}$ School of Studies in Biotechnology, Jiwaji University, Gwalior 474 002, India \\ ${ }^{4}$ National Centre for Cell Science, Pune 411 007, India
}

\begin{abstract}
A yellow-pigmented bacterial strain, R4-1 $\mathrm{A}^{\top}$, isolated from the midgut of the mosquito Culex quinquefasciatus (a vector of lymphatic filariasis), was studied using a polyphasic approach. Cells of the isolate were rod-shaped and stained Gram-negative. A comparison of the 16S rRNA gene sequence of this organism with sequences of type strains of the most closely related species clearly showed an allocation to the genus Chryseobacterium, with the highest sequence similarities (all 97.9\%) to Chryseobacterium jejuense $\mathrm{JS} 17-8^{\top}, \mathrm{C}$. indologenes ATCC $29897^{\top}$, C. arthrosphaerae CC-VM-7 ${ }^{\top}$ and $C$. aquifrigidense $C W 9^{\top}$. 16S rRNA gene sequence similarities to type strains of other Chryseobacterium species were below $97.5 \%$. The fatty acid profile of strain R4-1 $A^{\top}$ included the major fatty acids iso-15:0, summed feature 4 (comprising iso-15:0

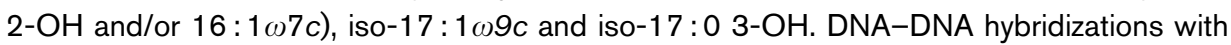
C. jejuense KACC $12501^{\top}$, C. indologenes CCUG $14556^{\top}$, C. arthrosphaerae CC-VM- $7^{\top}$ and C. aquifrigidense $\mathrm{KCTC} 12894^{\top}$ resulted in relatedness values of $38.3 \%$ (reciprocal $30.5 \%$ ), $29.4 \%(32.1 \%), 23.2 \%(37.2 \%)$ and $29.5 \%(47.1 \%)$, respectively. These results and the differentiating biochemical and chemotaxonomic properties show that strain R4-1 $A^{\top}$ represents a novel species, for which the name Chryseobacterium culicis sp. nov. is proposed. The type strain is $\mathrm{R} 4-1 \mathrm{~A}^{\mathrm{T}}$ (=LMG $25442^{\top}=\mathrm{CCM} 7716^{\top}$ ).
\end{abstract}

The genus Chryseobacterium was described by Vandamme et al. (1994) and at that time contained only five species, Chryseobacterium gleum (the type species), C. balustinum, C. indologenes, C. indoltheticum and C. scophthalmum. The number of species descriptions has since increased tremendously, and more than 30 species have been described in the last 15 years (e.g. Hugo et al., 2003; Li et al., 2003; de Beer et al., 2005; Shen et al., 2005; Shimomura et al., 2005; Young et al., 2005; Park et al., 2006; Tai et al., 2006; Herzog et al., 2008; Behrendt et al., 2008; Weon et al., 2008; Szoboszlay et al., 2008; Hantsis-Zacharov et al., 2008; Kim et al., 2005, 2008; Kämpfer et al., 2009, 2010). Representatives of the genus Chryseobacterium can be found in a wide variety of samples, including environmental but also clinical sources (Bernardet et al., 2006).

A yellow-pigmented strain from the midgut of the mosquito Culex quinquefasciatus Say was isolated on

Abbreviations: pNA, $p$-nitroanilide; pNP, $p$-nitrophenyl.

The GenBank/EMBL/DDBJ accession number for the 16S rRNA gene sequence of strain R4-1 $A^{\top}$ is FN554975. tryptic soy agar (TSA; Oxoid). This strain, R4-1A ${ }^{\mathrm{T}}$, was maintained and subcultivated on nutrient agar (NA) at $30{ }^{\circ} \mathrm{C}$ for $48 \mathrm{~h}$ and subsequently analysed for its $16 \mathrm{~S}$ rRNA gene sequence, fatty acid methyl ester composition of the whole cell hydrolysate, further phenotypic characteristics and DNA-DNA relatedness to the type strains of those species most closely related on the basis of $16 \mathrm{~S}$ rRNA gene sequence similarity.

Cultural and morphological characteristics were observed on NA. The Gram reaction was tested by the modified method of Gerhardt et al. (1994) and motility was assessed under the light microscope on cells grown for 3 days in nutrient broth $\left(\mathrm{NB}\right.$; Oxoid) at $30{ }^{\circ} \mathrm{C}$. Growth was investigated at $4,11,30,37$ and $45{ }^{\circ} \mathrm{C}$ in NB. Salt tolerance was also investigated at $0.5-8.0 \%(\mathrm{w} / \mathrm{v}) \mathrm{NaCl}$ in tryptic soy broth.

Strain R4-1A $\mathrm{A}^{\mathrm{T}}$ showed Gram-negative staining behaviour and formed visible (diameter about $2 \mathrm{~mm}$ ) yellowish colonies within $48 \mathrm{~h}$ at $30{ }^{\circ} \mathrm{C}$. No growth was observed below $5{ }^{\circ} \mathrm{C}$ or above $37^{\circ} \mathrm{C}$. Strain $\mathrm{R} 4-1 \mathrm{~A}^{\mathrm{T}}$ grew in the presence of up to $3.0 \% \mathrm{NaCl}$. Colonies were translucent 
and shiny with entire edges but, after prolonged incubation, the colonies were not visible as single entities, probably because of the profuse production of extracellular substances. A bright-yellow pigment of the flexirubin type (KOH method according to Reichenbach, 1989) was produced on NA. Oxidase activity was tested using the bioMérieux oxidase reagent according to the instructions of the manufacturer; strain $\mathrm{R} 4-1 \mathrm{~A}^{\mathrm{T}}$ showed a positive oxidase reaction. Cells were non-motile, non-spore-forming rods ( $1 \mu \mathrm{m}$ wide, $2 \mu \mathrm{m}$ long). Strain R4-1 $\mathrm{A}^{\mathrm{T}}$ grew well on NA, brain heart infusion agar and TSA and not on MacConkey agar (Oxoid).

Physiological characterization and additional biochemical tests were performed to assess the carbon source utilization pattern and the hydrolysis of chromogenic substrates was investigated as described by Kämpfer et al. (1991). The following additional biochemical tests were performed: production of hydrogen sulphide, using lead acetate paper and triple-sugar-iron methods, indole reaction with Ehrlich's and Kovács' reagent, activities of arginine dihydrolase, lysine decarboxylase, ornithine decarboxylase, DNase (Oxoid CM321; supplemented with $0.01 \%$ toluidine blue), $\beta$-galactosidase (ONPG) and urease on Christensen's urea agar and hydrolysis of casein, gelatin (plate method), starch and tyrosine (Smibert \& Krieg, 1994). Strain R4-1 $A^{\mathrm{T}}$ utilized few carbon sources, similar to all Chryseobacterium species, but was able to hydrolyse many chromogenic substrates. Urease, indole production and hydrolysis of casein, gelatin, starch and tyrosine were positive, while hydrogen sulphide production and activities of arginine dihydrolase, lysine decarboxylase, ornithine decarboxylase and $\beta$-galactosidase (ONPG) were negative. The results of biochemical and physiological tests are given in Table 1 and in the species description.

Table 1. Comparison of characteristics of strain $R 4-1 A^{\top}$ with those of the type strains of the most closely related Chryseobacterium species

Strains: 1, Chryseobacterium culicis sp. nov. R4-1 $\mathrm{A}^{\mathrm{T}} ; 2$, C. jejuense KACC $12501^{\mathrm{T}} ; 3$, C. indologenes CCUG $14556^{\mathrm{T}}$; 4, C. aquifrigidense KCTC $12894^{\mathrm{T}}$; 5, C. arthrosphaerae CC-VM-7 ${ }^{\mathrm{T}}$ (data from Kämpfer et al., 2010). Data were obtained in this study unless indicated. +, Positive; $(+)$, weakly positive; - , negative. All strains were able to produce acid from D-glucose and maltose, hydrolysed aesculin and produced indole from tryptophan. None of the strains produced acid from D-fructose, sucrose, L-arabinose, lactose or D-xylose.

\begin{tabular}{|lccccc|}
\hline Characteristic & $\mathbf{1}$ & $\mathbf{2}$ & $\mathbf{3}$ & $\mathbf{4}$ & $\mathbf{5}$ \\
\hline Growth on MacConkey agar & - & + & + & + & - \\
Acid production from: & & & & & \\
$\quad$ D-Mannitol & + & - & - & - & $(+)$ \\
$\quad$ Trehalose & + & + & + & + & - \\
Nitrate reduction & - & - & + & - & + \\
Urease activity & + & + & - & + & + \\
\hline
\end{tabular}

Cellular fatty acid analysis of whole-cell hydrolysates was performed according to Kämpfer \& Kroppenstedt (1996) and revealed that the following fatty acids were most abundant: iso-15:0, summed feature 4 (iso-15:0 2-OH and/or $16: 1 \omega 7 c$ ), iso- $17: 1 \omega 9 c$ and iso-17:0 $3-\mathrm{OH}$. The complete fatty acid pattern of strain $\mathrm{R} 4-1 \mathrm{~A}^{\mathrm{T}}$ is shown in Table 2 in comparison with those of the type strains of the most closely related Chryseobacterium species.

The 16S rRNA gene of strain $\mathrm{R} 4-1 \mathrm{~A}^{\mathrm{T}}$ was sequenced as described by Kämpfer et al. (2003). Subsequent analysis was performed using the ARB software package (Ludwig et al., 2004) and the corresponding SILVA SSURef 95 database (version July 2008; Pruesse et al., 2007) as well as the software package MEGA version 4.0 (Tamura et al., 2007) after multiple alignment of data by CLUSTAL_X (Thompson et al., 1997). The sequenced length of the 16S rRNA gene was $1387 \mathrm{bp}$. Nucleotide sequence

Table 2. Long-chain fatty-acid compositions of strain $R 4-1 A^{T}$ and type strains of related Chryseobacterium species

Strains: 1, C. culicis sp. nov. R4-1A ${ }^{\mathrm{T}} ; 2$, C. jejuense KACC $12501^{\mathrm{T}} ; 3$, C. indologenes CCUG $14556^{\mathrm{T}}$; 4, C. aquifrigidense KCTC $12894^{\mathrm{T}} ; 5$, C. arthrosphaerae $\mathrm{CC}-\mathrm{VM}-7^{\mathrm{T}}$. Values are percentages of total fatty acids; components amounting to less than $1 \%$ of the total fatty acids in all strains are not included. tr, Trace (less than $1.0 \%$ ); ND, not detected. Data in column 5 were taken from Kämpfer et al. (2010) and data in parentheses in column 3 (obtained from cells grown on TSA at $20{ }^{\circ} \mathrm{C}$ for $24 \mathrm{~h}$ ) are means \pm SD taken from a survey of 45 strains (Hugo et al., 2003); other data were obtained in this study.

\begin{tabular}{|lccccc|}
\hline Fatty acid & $\mathbf{1}$ & $\mathbf{2}$ & $\mathbf{3}$ & $\mathbf{4}$ & $\mathbf{5}$ \\
\hline iso-13:0 & $\operatorname{tr}$ & 1.0 & $\mathrm{ND}(\mathrm{tr})$ & $\mathrm{ND}$ & $\mathrm{tr}$ \\
Unknown $13.566^{*}$ & 8.7 & 8.5 & $13.1(21 \pm 0.7)$ & 4.2 & 20.5 \\
iso-15:0 & 33.9 & 31.2 & $28.5(34.3 \pm 4.9)$ & 36.2 & 32.3 \\
anteiso-15:0 & $\operatorname{tr}$ & $\operatorname{tr}$ & $\mathrm{ND}$ & $\mathrm{ND}$ & $\mathrm{ND}$ \\
iso-15:0 3-OH & 2.5 & 2.5 & $2.1(2.6 \pm 0.2)$ & 3.0 & 1.0 \\
iso-15:1 F & $\operatorname{tr}$ & $\operatorname{tr}$ & $3.4(\mathrm{ND})$ & $\mathrm{ND}$ & 4.6 \\
$16: 0$ & 1.8 & 1.7 & $1.2(\mathrm{tr})$ & 1.8 & 1.6 \\
$15: 03-\mathrm{OH}$ & 1.0 & $\mathrm{ND}$ & $\mathrm{ND}$ & $\mathrm{ND}$ & $\mathrm{ND}$ \\
$16: 03-\mathrm{OH}$ & 1.3 & 1.3 & $\operatorname{tr}(1.0 \pm 0.2)$ & 2.3 & $\mathrm{ND}$ \\
Unknown 16.580* & 1.3 & 1.2 & $1.3(1.7 \pm 0.2)$ & 1.2 & 1.7 \\
$17: 02-\mathrm{OH}$ & $\mathrm{ND}$ & $\mathrm{ND}$ & $\mathrm{ND}(\mathrm{ND})$ & $\mathrm{ND}$ & 2.0 \\
iso-17:0 & 1.3 & 1.5 & $1.1(\mathrm{tr})$ & 1.0 & 2.0 \\
iso-17:0 3-OH & 15.5 & 15.4 & $14.4(19.2 \pm 1.8)$ & 18.2 & 3.5 \\
iso-17:1 $\omega 9 c$ & 20.7 & 21.9 & $23.4(24.2 \pm 3.1)$ & 17.3 & 18.9 \\
Summed feature & 10.0 & 11.0 & $9.8(11.1 \pm 1.3)$ & 13.8 & 5.5 \\
$4 \dagger$ & & & & & \\
Summed feature & $\mathrm{ND}$ & $\mathrm{ND}$ & $\operatorname{tr}(\mathrm{tr})$ & $\mathrm{ND}$ & 1.0 \\
$5 \dagger$ & & & & & \\
\hline
\end{tabular}

${ }^{*}$ Unknown fatty acids; numbers indicate the equivalent chain-length. $\dagger$ Fatty acids that could not be separated by GC using the Microbial Identification System (Microbial ID) software were considered summed features. Summed feature 4 contains iso-15:0 2-OH and/ or $16: 1 \omega 7 c$. Summed feature 5 contains iso-17:1 I and/or anteiso$17: 1 \mathrm{~B}$. 
distances were calculated (distance options according to the Kimura-2 model) using the software package MEGA version 4.0 (Tamura et al., 2007).

The tree shown in Fig. 1 is based on a maximum-likelihood reconstruction (only alignment columns in which the frequency of the most abundant nucleotide was $\geqslant 50 \%$ were included in the calculation). The topologies of the neighbour-joining and maximum-parsimony trees were congruent (not shown). Strain R4-1A $\mathrm{T}^{\mathrm{T}}$ clearly grouped most closely with Chryseobacterium jejuense JS17-8 ${ }^{\mathrm{T}}$.

According to the sequence similarity calculations, the type strains most closely related to strain $\mathrm{R} 4-1 \mathrm{~A}^{\mathrm{T}}$ were C. jejuense JS17- ${ }^{\mathrm{T}}$, Chryseobacterium indologenes ATCC
$29897^{\mathrm{T}}$, Chryseobacterium aquifrigidense $\mathrm{CW} 9^{\mathrm{T}}$ and Chryseobacterium arthrosphaerae CC-VM- $7^{\mathrm{T}}$, all showing $97.9 \%$ sequence similarity, while sequence similarities were below $97.5 \%$ for the type strains of other Chryseobacterium species.

DNA-DNA hybridization experiments were performed between strain R4-1A ${ }^{\mathrm{T}}$ and the type strains of the four most closely related Chryseobacterium species according to the method of Ziemke et al. (1998) (except that, for nick translation, $2 \mu \mathrm{g}$ DNA was labelled for $3 \mathrm{~h}$ at $15{ }^{\circ} \mathrm{C}$ ). Strain R4- $1 \mathrm{~A}^{\mathrm{T}}$ showed relatively low DNA-DNA hybridization to C. jejuense KACC $12501^{\mathrm{T}}$ (38.3\%; reciprocal $\left.30.5 \%\right)$, C. indologenes CCUG $14556^{\mathrm{T}}(29.4 / 32.1 \%)$, C. aquifrigidense

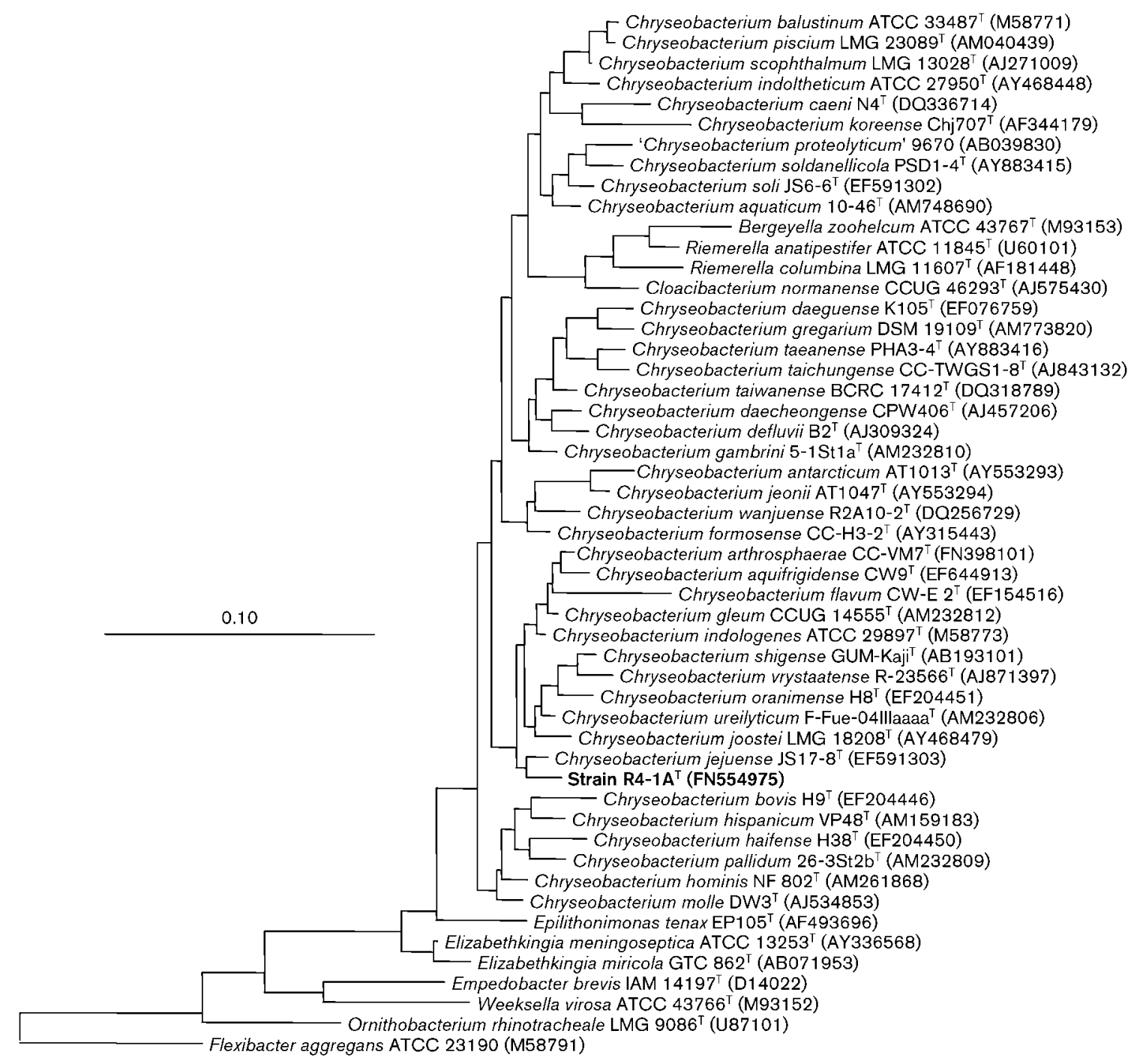

Fig. 1. Phylogenetic analysis of strains most closely related to strain $R 4-1 A^{\top}$ based on $16 \mathrm{~S}$ rRNA gene sequences available from the EMBL database (accession numbers in parentheses). The tree was constructed using the ARB software package (version December 2007; Ludwig et al., 2004) and the corresponding SILVA SSURef 95 database (version July 2008; Pruesse et al., 2007). The sequence of Flexibacter aggregans ATCC 23190 was used as an outgroup. Tree building was performed using the maximum-likelihood method with fastDNAml (Olsen et al., 1994). Bar, 0.10 substitutions per nucleotide position. 
KCTC $12894^{\mathrm{T}}(23.2 / 37.2 \%)$ and C. arthrosphaerae CCVM-7 ${ }^{\mathrm{T}}(29.5 / 47.1 \%)$.

On the basis of the results of this polyphasic study, it is clear that strain $\mathrm{R} 4-1 \mathrm{~A}^{\mathrm{T}}$ represents a novel species of the genus Chryseobacterium, for which the name Chryseobacterium culicis sp. nov. is proposed.

\section{Description of Chryseobacterium culicis sp. nov.}

Chryseobacterium culicis [cu.li'cis. L. n. culex -icis a gnat, a midge, and also a genus of mosquito (Culex, family Culicidae); N.L. gen. n. culicis of Culex, referring to the isolation of the type strain from Culex quinquefasciatus].

Cells are Gram-staining-negative, non-motile, non-sporeforming rods, approx. $1 \mu \mathrm{m}$ wide and $2 \mu \mathrm{m}$ long. Aerobic, oxidase-positive and catalase-positive. Good growth occurs at $11-36{ }^{\circ} \mathrm{C}$ after $48 \mathrm{~h}$ on NA, brain heart infusion agar and TSA (all Oxoid). No growth on MacConkey agar (Oxoid) at $28{ }^{\circ} \mathrm{C}$. The type strain is unable to grow at 4 or $45^{\circ} \mathrm{C}$. Grows in the presence of $0.5-3.0 \% \mathrm{NaCl}$. Colonies on NA are smooth, yellowish, circular, translucent and shiny with entire edges. Colonies become mucoid and cannot be identified as single entities after prolonged incubation. The yellow pigment of the flexirubin type is non-diffusible and non-fluorescent. Produces acid weakly from D-glucose, trehalose and D-mannitol. No acid is produced from adonitol, L-arabinose, D-arabitol, dulcitol, erythritol, myoinositol, lactose, maltose, melibiose, methyl $\alpha$-D-glucoside, raffinose, L-rhamnose, salicin, D-sorbitol, sucrose or Dxylose. Urease activity, indole production and hydrolysis of casein, gelatin, starch, DNA and tyrosine are positive, while hydrogen sulphide production and activities of arginine dihydrolase, lysine decarboxylase, ornithine decarboxylase and $\beta$-galactosidase (ONPG) are negative. D-Glucose, maltose, D-mannose, D-fructose and trehalose are utilized as sole sources of carbon. The following compounds are not utilized as sole sources of carbon: acetate, propionate, $\mathrm{N}$-acetylgalactosamine, $\mathrm{N}$-acetylglucosamine, L-arabinose, L-arbutin, cellobiose, D-galactose, gluconate, glycerol, D-mannitol, maltitol, melibiose, L-rhamnose, D-ribose, sucrose, salicin, D-xylose, adonitol, myo-inositol, D-sorbitol, putrescine, cis- and trans-aconitate, 4-aminobutyrate, adipate, azelate, fumarate, glutarate, DL-3-hydroxybutyrate, itaconate, DL-lactate, 2-oxoglutarate, pyruvate, suberate, citrate, mesaconate, L-alanine, $\beta$-alanine, L-ornithine, Lphenylalanine, L-serine, L-aspartate, L-histidine, L-leucine, L-proline, L-tryptophan, 3-hydroxybenzoate, 4-hydroxybenzoate and phenylacetate. The chromogenic substrates $p$-nitrophenyl (pNP) $\alpha$-D-glucopyranoside, pNP $\beta$-D-glucopyranoside (weak), pNP $\beta$-D-galactopyranoside, bis-pNP phosphate, bis-pNP phenylphosphonate, bis-pNP phosphorylcholine, 2-deoxythymidine-2'-pNP phosphate, Lalanine $p$-nitroanilide (pNA), $\gamma$-L-glutamate pNA and L-proline pNA are hydrolysed. pNP $\beta$-D-xylopyranoside and $\mathrm{pNP} \beta$-D-glucuronide are not hydrolysed. The major cellular fatty acids $(\geqslant 10 \%)$ are iso-15:0, summed feature 4 (iso-15:0 2-OH and/or $16: 1 \omega 7 c$ ), iso- $17: 1 \omega 9 c$ and iso-17:0 $3-\mathrm{OH}$.

The type strain is $\mathrm{R} 4-1 \mathrm{~A}^{\mathrm{T}}\left(=\mathrm{LMG} 25442^{\mathrm{T}}=\mathrm{CCM} 7716^{\mathrm{T}}\right)$, isolated from the midgut of the mosquito Culex quinquefasciatus (a vector of lymphatic filariasis) collected from the filarial endemic region of Raipur (Chattishgarh province), India.

\section{Acknowledgements}

Authors are thankful to Dr R. Vijayraghavan, Director, Defence R \& D Establishment, Gwalior, for constant encouragement and keen interest in this work. We thank Dr Jean Euzéby for his helpful advice on the specific epithet. We also thank Dr S.-W. Kwon for kindly providing the type strain of C. jejuense. K. C. is thankful to Dr A. K. Gupta, Pandit Ravishankar Shukla University, Raipur, for help in collecting mosquitoes from the Raipur region.

\section{References}

Behrendt, U., Ulrich, A. \& Schumann, P. (2008). Chryseobacterium gregarium sp. nov., isolated from decaying plant material. Int J Syst Evol Microbiol 58, 1069-1074.

Bernardet, J.-F., Bruun, B. \& Hugo, C. (2006). The genera Chryseobacterium and Elizabethkingia. In The Prokaryotes, a Handbook on the Biology of Bacteria, 3rd edn, vol. 7, pp. 638-676. Edited by M. Dworkin, S. Falkow, E. Rosenberg, K. H. Schleifer \& E. Stackebrandt. New York: Springer.

de Beer, H., Hugo, C. J., Jooste, P. J., Willems, A., Vancanneyt, M., Coenye, T. \& Vandamme, P. A. R. (2005). Chryseobacterium vrystaatense sp. nov., isolated from raw chicken in a chickenprocessing plant. Int J Syst Evol Microbiol 55, 2149-2153.

Gerhardt, P., Murray, R. G. E., Wood, W. A. \& Krieg, N. R. (editors) (1994). Methods for General and Molecular Bacteriology. Washington, DC: American Society for Microbiology.

Hantsis-Zacharov, E., Shaked, T., Senderovich, Y. \& Halpern, M. (2008). Chryseobacterium oranimense sp. nov., a psychrotolerant, proteolytic and lipolytic bacterium isolated from raw cow's milk. Int $J$ Syst Evol Microbiol 58, 2635-2639.

Herzog, P., Winkler, I., Wolking, D., Kämpfer, P. \& Lipski, A. (2008). Chryseobacterium ureilyticum sp. nov., Chryseobacterium gambrini sp. nov., Chryseobacterium pallidum sp. nov. and Chryseobacterium molle sp. nov., isolated from beer-bottling plants. Int J Syst Evol Microbiol 58, 26-33.

Hugo, C. J., Segers, P., Hoste, B., Vancanneyt, M. \& Kersters, K. (2003). Chryseobacterium joostei sp. nov., isolated from the dairy environment. Int J Syst Evol Microbiol 53, 771-777.

Kämpfer, P. \& Kroppenstedt, R. M. (1996). Numerical analysis of fatty acid patterns of coryneform bacteria and related taxa. Can $J$ Microbiol 42, 989-1005.

Kämpfer, P., Steiof, M. \& Dott, W. (1991). Microbiological characterization of a fuel-oil contaminated site including numerical identification of heterotrophic water and soil bacteria. Microb Ecol 21, 227-251.

Kämpfer, P., Dreyer, U., Neef, A., Dott, W. \& Busse, H.-J. (2003). Chryseobacterium defluvii sp. nov., isolated from waste water. Int $J$ Syst Evol Microbiol 53, 93-97.

Kämpfer, P., Vaneechoutte, M. \& Wauters, G. (2009). Chryseobacterium arothri Campbell et al. 2008 is a later heterotypic 
synonym of Chryseobacterium hominis Vaneechoutte et al. 2007. Int J Syst Evol Microbiol 59, 695-697.

Kämpfer, P., Arun, A. B., Young, C.-C., Chen, W.-M., Sridhar, K. R. \& Rekha, P. D. (2010). Chryseobacterium arthrosphaerae sp. nov., isolated from the faeces of the pill millipede Arthrosphaera magna Attems. Int J Syst Evol Microbiol 60, 1765-1769.

Kim, K. K., Bae, H.-S., Schumann, P. \& Lee, S.-T. (2005). Chryseobacterium daecheongense sp. nov., isolated from freshwater lake sediment. Int J Syst Evol Microbiol 55, 133-138.

Kim, K. K., Lee, K. C., Oh, H. M. \& Lee, J. S. (2008). Chryseobacterium aquaticum sp. nov., isolated from a water reservoir. Int J Syst Evol Microbiol 58, 533-537.

Li, Y., Kawamura, Y., Fujiwara, N., Naka, T., Liu, H., Huang, X., Kobayashi, K. \& Ezaki, T. (2003). Chryseobacterium miricola sp. nov., a novel species isolated from condensation water of space station Mir. Syst Appl Microbiol 26, 523-528.

Ludwig, W., Strunk, O., Westram, R., Richter, L., Meier, H., Yadhukumar, Buchner, A., Lai, T., Steppi, S. \& other authors (2004). ARB: a software environment for sequence data. Nucleic Acids Res 32, 1363-1371.

Olsen, G. J., Matsuda, H., Hagström, R. \& Overbeek, R. (1994). fastDNAml: a tool for construction of phylogenetic trees of DNA sequences using maximum likelihood. Comput Appl Biosci 10, 41-48.

Park, M. S., Jung, S. R., Lee, K. H., Lee, M.-S., Do, J. O., Kim, S. B. \& Bae, K. S. (2006). Chryseobacterium soldanellicola sp. nov. and Chryseobacterium taeanense sp. nov., isolated from roots of sand-dune plants. Int J Syst Evol Microbiol 56, 433-438.

Pruesse, E., Quast, C., Knittel, K., Fuchs, B. M., Ludwig, W., Peplies, J. \& Glöckner, F. O. (2007). SILVA: a comprehensive online resource for quality checked and aligned ribosomal RNA sequence data compatible with ARB. Nucleic Acids Res 35, 7188-7196.

Reichenbach, H. (1989). Genus I Cytophaga Winogradsky 1929, $577^{\mathrm{AL}}$, emend. In Bergey's Manual of Systematic Bacteriology, vol. 3, pp. 2015-2050. Edited by J. T. Staley, M. P. Bryant, N. Pfennig \& J. G. Holt. Baltimore: Williams \& Wilkins.

Shen, F. T., Kämpfer, P., Young, C. C., Lai, W. A. \& Arun, A. B. (2005). Chryseobacterium taichungense sp. nov., isolated from contaminated soil. Int J Syst Evol Microbiol 55, 1301-1304.
Shimomura, K., Kaji, S. \& Hiraishi, A. (2005). Chryseobacterium shigense sp. nov., a yellow-pigmented, aerobic bacterium isolated from a lactic acid beverage. Int J Syst Evol Microbiol 55, 19031906.

Smibert, R. M. \& Krieg, N. R. (1994). Phenotypic characterization. In Methods for General and Molecular Bacteriology, pp. 607-654. Edited by P. Gerhardt, R. G. E. Murray, W. A. Wood \& N. R. Krieg. Washington, DC: American Society for Microbiology.

Szoboszlay, S., Atzel, B., Kukolya, J., Toth, E. M., Marialigeti, K., Schumann, P. \& Kriszt, B. (2008). Chryseobacterium hungaricum sp. nov., isolated from hydrocarbon-contaminated soil. Int J Syst Evol Microbiol 58, 2748-2754.

Tai, C.-J., Kuo, H.-P., Lee, F.-L., Chen, H.-K., Yokota, A. \& Lo, C.-C. (2006). Chryseobacterium taiwanense sp. nov., isolated from soil in Taiwan. Int J Syst Evol Microbiol 56, 1771-1776.

Tamura, K., Dudley, J., Nei, M. \& Kumar, S. (2007). MEGA4: molecular evolutionary genetics analysis (MEGA) software version 4.0. Mol Biol Evol 24, 1596-1599.

Thompson, J. D., Gibson, T. J., Plewniak, F., Jeanmougin, F. \& Higgins, D. G. (1997). The CLUSTAL_X windows interface: flexible strategies for multiple sequence alignment aided by quality analysis tools. Nucleic Acids Res 25, 4876-4882.

Vandamme, P., Bernardet, J.-F., Segers, P., Kersters, K. \& Holmes, B. (1994). New perspectives in the classification of the flavobacteria: description of Chryseobacterium gen. nov., Bergeyella gen. nov., and Empedobacter nom. rev. Int J Syst Bacteriol 44, 827831.

Weon, H. Y., Kim, B. Y., Yoo, S. H., Kwon, S. W., Stackebrandt, E. \& Go, S. J. (2008). Chryseobacterium soli sp. nov. and Chryseobacterium jejuense sp. nov., isolated from soil samples from Jeju, Korea. Int J Syst Evol Microbiol 58, 470-473.

Young, C. C., Kämpfer, P., Shen, F. T., Lai, W. A. \& Arun, A. B. (2005). Chryseobacterium formosense sp. nov., isolated from the rhizosphere of Lactuca sativa L. (garden lettuce). Int J Syst Evol Microbiol 55, 423426.

Ziemke, F., Höfle, M. G., Lalucat, J. \& Rosselló-Mora, R. (1998). Reclassification of Shewanella putrefaciens Owen's genomic group II as Shewanella baltica sp. nov. Int J Syst Bacteriol 48, 179-186. 